\title{
Towards an Africa Philosophy of Education for Indigenous Knowledge Systems in Africa
}

\author{
Edmore Mutekwe \\ Vaal University of Technology, Vanderbijlpark, South Africa \\ Email: edmorem@vut.ac.za
}

Received 1 May 2015; accepted 5 July 2015; published 8 July 2015

Copyright (C) 2015 by authors and Scientific Research Publishing Inc.

This work is licensed under the Creative Commons Attribution International License (CC BY). http://creativecommons.org/licenses/by/4.0/

(c) (i) Open Access

\begin{abstract}
The argument in this conceptual paper is that the advent of modern type western education has resulted in the dearth of the importance of indigenous forms of knowledge in Africa. The paper unfolds by highlighting some of the areas in which the modern Eurocentric philosophy of education has alienated and affected some of Africa's indigenous education systems. Using the modernization paradigm as the framework, the paper's contention is that following missionary excursions in Africa and the subsequent colonisation, modern forms of schooling were introduced and expanded phenomenally and with it came notions of cultural imperialism, which tended to denigrate many if not all forms of indigenous knowledge education systems. Some indigenous knowledge systems were regarded as primitive, pagan and heathenish. Some forms of such indigenous knowledge were even de-campaigned as non-knowledge. The research question the paper seeks to address is how can indigenous knowledge education systems be used to foster an Afrocentric philosophy of Education? Pursuant to this question, the modernization theory is examined, unpacked and critiqued for equating modernisation with Westernization culminating in the promotion of cultural imperialist sentiments that had an alienating effect on some African institutions and practices.
\end{abstract}

\section{Keywords}

Afrocentrism, Centre, Periphery, Heathen, Indigenous Knowledge Systems, Modernity, Ubuntu

\section{Introduction}

The argument proffered in this paper is that schools, colleges and universities for many African nations should develop a whole and well-rounded person with unhu or ubuntu, youths and adults who are loyal, responsible, productive and respectful of the laws, rules, customs and traditions of their societies. Mahoso (2013) contends that it is a majority belief that citizenship education would develop patriotism, obedience to legitimate authority 
and respect for other citizens' views on various social, economic and political issues. However, the recent outbreak of xenophobic attacks on foreign nationals in the Republic of South Africa has shown that it (citizenship education) only trains children and adults in Africa to appreciate the roles, functions and responsibilities of members of parliament, ministers of government, governmental institutions, civil servants, local authorities and communities but not the rights and privileges of citizens of other nations resident in their country (Chivaura, 2014). Current statistics of South Africa's educational output (Department of Education, 2014) shows that some children leave primary and secondary school with scanty and incorrect knowledge of their history, heritage, pan-Africanism, integrity, commitment, strategic intelligence, strategic realignment with national priorities, moral and ethical values of unhu or ubuntu and it is no surprise these are some of the candidates rogue politicians recruit and mobilise to carry out such atrocities as xenophobic attacks on citizens of other African nations resident in their country (Mahoso, 2014). This development certainly reduces the African philosophy of education to mere obedience and conformity not even with the Eurocentric conventional school.

\section{Background to the Study}

Mahoso (2013) maintains that for the last 100 - 300 years Africans have been exposed to three anti-African philosophies of education. These include the white conservative missionary model as espoused by King Leopold 2 of Belgium in an address to Belgian missionaries 1883. This model recognised that Africans already knew God and did not need white missionaries to know God and to acquire knowledge and wisdom (Mahoso, 2013). So the purpose of missionary education was to manipulate the bible and the African's knowledge of God in order to suppress African potential (Chivaura, 2014). The second philosophy examined in the discussion is the white liberal missionary view, which took the notion of education as drawing out and leading forth, literally to mean helping the African to flee from Ubuntu and become a third rate European (Mufuka, 2014). This is the linear, crusading approach to African education as an escape or retreat from Africanness. The apartheid and Rhodesian states' idea of Bantu education was a secular system for training Africans to be productive labourers and clerks at the lowest levels of industry while recognising their separate, indigenous African origins only for purposes of segregation (Chivaura, 2014). The South African apartheid model sought to limit African education to the equivalent of training, thereby viewing education as mechanical training. This philosophy was spelt out in the South African Bantu Education Act and the Rhodesian Native Act. PW Botha repeated it as late as 1985 when he said, 'the strength of our (apartheid) economy is backed by America, Britain and German (Mda, 2007). It is our strong conviction that the black is the raw material for the white man' (Mahoso, 2013). Among other African writers and scholars, Chivaura (2014) has drawn parallels from the bible on the need for an Afrocentric philosophy by documenting the African origins of the bible and arguing that the African relational philosophy of education is akin to the model implied in the bible, whereby Joseph was educated in Africa where he finally rose to become Prime Minister of Egypt. Moses was educated in Africa where the fruits of that education were evident in his leadership and in the first five biblical books of the Old Testament, the Pentateuch (Adam \& Wesley, 2003). Jesus was also a child refugee in Africa. The Greeks were educated in Africa and their education was an adaption from African educational approaches.

Mahoso (2013) contends that one of the striking paradoxes of education in Africa arises from the fact that the white missionaries who started Western type schools in Southern Africa did not follow the philosophy of education implied in the bible but the dictates of imperialism and settlerism, which meant that the colonial African learner had to be constituted as an escapee, as a run-away from his or her ubuntu. This is important because much of the bible is African in origin and the approach to learning is implied, for example, in the life of Jesus Christ, is the opposite of the colonial approach. An example can be drawn from the Luke chapter 2: 41 - 52, where Jesus when he was 12 years old and his parents went up to Jerusalem according to their custom to the feast and when it was over, as they were returning, the boy Jesus stayed behind in Jerusalem without his parents' knowledge and when they realised he was not with them, they went up looking for him among their relatives. After three days they found him in the temple, sitting with elders and the professors, listening to them and asking questions. And all who heard him were amazed at his understanding and his answers. And when his parents saw him, they were astonished and his mother said to him, "Son, why have you treated us so? Your father and I have been searching for you in great distresses." His response to them that they did not need to look for him but to know that he had to be in his father's house attest to the aforementioned view of the education philosophy implicit in the bible, which Western education pioneers in Africa overlooked. In the next section the focus is on the theoretical framework used as the lens for this discussion. 


\section{Theoretical Framework}

The modernization paradigm adopted as the lens for the discussion in this paper, emerged in the 1950s as an explanation of how the industrial societies of North America and Western Europe developed (Crossman, 2012). The theory argues that societies develop in fairly predictable stages though which they become increasingly complex. Development depends primarily on the importation of technology as well as a number of other political and social changes believed to come about as a result. Crossman (2012) further notes that the modernization perspective involves increased levels of schooling and the development of mass media, both of which foster democratic political institutions. Traditional practices and values in primitive societies become obsolete as modernity sets in due to cultural diffusion from the centre to the periphery (Frank, 1972) of the globe.

Modernization is thus linked to globalization, which Cole (2010) defines an ongoing process involving shifts in economic, cultural, and political spheres of society, and the overall increasing nature of global integration of these aspects of nations, regions, communities, and even seemingly isolated locales. For him, in terms of the economy, it refers to the expansion of the capitalist economy to include all places around the world into one globally integrated economic system. Cole (2010) further notes that culturally, it refers to the global spread and integration of ideas, values, norms, behaviours, and ways of life. Politically, it refers to the development of forms of governance that operate at the global scale, whose policies and rules cooperative nations are expected to abide. These three core aspects of globalization are all fuelled by technological development, the global integration of communication technologies, and the global distribution of media (Webster, 2008). Transportation and communication become increasingly sophisticated and accessible, as populations become more urbanized and mobile, and the extended family declines in importance as a result (Webster, 2008). Organizations become bureaucratic as the division of labour grows more complex and religion declines in public influence (Christie, 1992). Lastly, cash-driven markets take over as the primary mechanism through which goods and services are exchanged. According to Ntalaga (2005) to many Africans concepts development, modernization and globalization imply adopting western cultural practices (westernization) and the processes relegate African culture to a secondary position. He thus defines development and modernization as a process by which Africans are to reach the levels of progress reached by western nations (Ntalaga, 2005). Seen in this light, the perception of modernity, globalization and development as synonymous with westernization carries with it a Eurocentric mind-set that subjugates African culture and creates a desire for a westernized culture among the Africa child and even adult. It denigrates African indigenous knowledge systems by creating a superiority complex for western forms of education (modernity). In the next section the focus is on how putting a robust language policy for education can foster value addition of indigenous knowledge systems and buttress and Afrocentric philosophy of education. Applied to the subject of indigenous knowledge systems, the modernization paradigm leads some Africans to view indigenous Knowledge Systems as incompatible with education (Maila \& Loubser, 2003). This view is based on the absolutisation of Indigenous Knowledge Systems of Africa's indigenous people and the perception that western traditions of knowing are the best (Ntuli, 2009: p. 188).

Coupled with the above notion is the assumption that Africa was a tabula rasa before the colonial era (that is a continent with no civilization)and that western cultural systems of knowledge were regarded as the only means to be used in determining the value of Africa's ideas, beliefs and general way of life (Ntuli, 2009). It is therefore crucial that Africa builds on all the valuable indigenous capitals of the past and relinquishes all that is deskilling or disempowering and disastrous to her development, advancement and sustainability. Rather than developing an ecologically coded African society which excludes the traditions of knowing of other peoples, an inclusive system and process of traditional knowledge should be deliberately and vigorously sought and implemented in the education system of the country (Maila \& Loubser, 2003). Such an approach will not only be enriching, but will ensure that mistakes of the past are never repeated in regard to elevating a particular knowledge system above another. A holistic knowledge framework for humanity is critical if Africa wishes to respond swiftly and appropriately to an educational crisis facing its people as a consequence of cultural imperialism (Vilakazi, 1999). This view is supported by Odora-Hoppers (2001: p. 17), Vilakazi (1999), Ntuli (2009), Hountondji (2002), and Semali and Kincheloe (1999).

\section{Conceptualizations of African Indigenous Knowledge Systems}

Emeagwali (2003) contends that resolving theoretical and conceptual issues about the identity of African Indigenous Knowledge Systems (AIKS) is in fact one of the many challenges confronting African philosophers, 
historians, anthropologists and educators. There are numerous other theoretical and methodological puzzles, most of which would best be resolved in structured discussions within an institutional framework, in the context of a planned curriculum and formalized discourse (Emeagwali, 2003). European philosophers of science from Popper to Lakatos, and Kuhn to Feyerabend have spent an inordinate amount of time discussing the nature of rationality, objectivity and problem solving in mainstream science. African philosophers of education also need to do the same for AIK so as to either reject, accept, modify or adapt relevant conceptual baggage in the field, and possibly create entirely new constructs of analysis for understanding the phenomenon, where necessary.

Indigenous knowledge is also sometimes termed traditional, endogenous or classical knowledge, and its Eurocentric critics allege that it often fails to contribute to the improvement of the quality of human life (Maila \& Loubser, 2003). This failure can be attributed purely to the lower status accorded to this type of knowledge in society. This knowledge is accorded low status because it belongs to a particular racial or ethnic group which often, it is assumed, lacks the necessary cultural capital (Bourdieu, 2002). Despite these negative perceptions of Indigenous Knowledge, there is a growing realisation that this knowledge is part of the global heritage and a national resource to be utilized for the benefit of all humanity (Green, 2006). This paper thus presents an argument that there is a major role to be played by Indigenous Knowledge Systems in education in general and African communities in particular. The contention presented in this discussion is that the denigration of AIKS stems from the assumption that Africa was a clean slate (tabula rasa) until Europeans arrived (Ntuli, 2009: p. 188). However, as maintained by Brokensha, Warren and Werner (2000), this view has been proved to be based on a narrow perception of knowledge as a universal resource. The misconception that western cultural knowledge orientations are the benchmarks for determining the value of blacks' ideas, belief systems and religion also exacerbated the cultural imperialist view of IKS as inferior to its Eurocentric counterpart (Ntuli, 2009: p. 188). With educational and environmental problems becoming more diverse and complex every day (Maila, 2001: p. 2), the world should now realise and try to tape from and utilise IKS in order to deal with some of the challenges at hand. It is imperative that all ways of knowing, whether indigenous or modern; Western or African, be explored and their valuable capital (skills, values and wisdom) be integrated into all educational frameworks that would take a people forward (Le Grange, 2000). Knowledge as a national heritage and a national resource should never be estranged from its social milieu (Masuku-Van Damme, 2007). The discussion thus explicates some of the valuable custodians of Indigenous Knowledge Systems with suggestions made to steer them forward in their endeavours to embrace Indigenous Knowledge systems for the benefit of the local educational landscape (McNeely, 2009).

The need for the inclusion of AIK in the curriculum of schools, colleges and universities transcends the aforementioned issues. It is, however important to note that no matter how significant the latter objective may be, there are social, psychological, anthropological, intellectual and economic reasons that basically stem from the mode of evolution of the historical process in the continent, as well as the structures of intellectual dominance and the dependence associated with colonial and postcolonial hierarchies and power elites (Christie, 2008). Several strategies of disinformation are clearly embedded in Eurocentric, colonial and post-colonial education systems and these include the selective omission of non-European achievements, inventions and technologies, the distortion of data, surreptitious naming and several other strategies of cultural imperialism and endeavours at recolonization (Odora-Hoppers, 2002). It is in this sense that this paper maintains that the recognition and appreciation of IKS is a source of healing of therapeutic import, in the context of unhealthy imbalances, distortion, trivialization and neglect, as inflicted by Eurocentric education and governance (Mavhunga, 2009).

The discourse on indigenous knowledge transmission to the youths can be clarified by, amongst others, Durkheim's (1960) view of schooling as the influence exercised by the adult generation on those who are not yet ready for social life (Blackledge \& Hunt, 2005). Its object is to develop a certain number of physical, intellectual and moral states that are demanded of the youth by the political, social and economic organisation of society as a whole and the special milieu for which they are specifically destined. Adopting a socio-historical approach, Durkheim (1960) contends that schooling takes different forms at different historical times and places. He notes that one cannot separate the education system from its society because the two reflect each other. He further stressed that in every place and time, education is closely related to other institutions and to the indigenous values and beliefs of that society (Christie \& Collins, 1990).

The social values and indigenous knowledge systems transmitted through schooling are, for Durkheim, the foundation of the social order and society perpetuated through its educational institutions. Although any change in society's history would naturally reflect a change in that society's education and or schooling and vice versa, 
it is important to note that indigenous forms of knowledge are essential for the maintenance of society in a true Durkheimian sense. This kind of knowledge (often also referred to as propositional knowledge) has been viewed as having three necessary and logically interdependent components: belief, justification and truth (Horsthemke, 2004). In practice, these components imply that in order for a person to know something, one has to believe and be able to justify one's belief in it. In addition, it has to be true (Hountondji, 2005). Each component is considered essential (Horsthemke, 2004). In isolation they do not amount to knowledge, and only in combination are they considered sufficient. This conceptualisation of knowledge has been contested mainly with regard to the adequacy of the three conditions (Gettier, 1963), namely that a person's justification for believing should be suitably connected to his belief about the truth. Furthermore, even if these conditions were jointly sufficient for knowledge, there remains considerable debate over what the justification condition involves, what degree is required and what kind is appropriate (Horsthemke, 2004).

Advocates of the indigenous knowledge genre, for example, Odora-Hoppers (2002), Hountondji (2005) and Semali and Kincheloe (1999) maintain that its curriculum, though informal, had a profound effect on children's socialisation into their cultural heritage and the maintenance of political and social cohesion (see for example, Odora-Hoppers, 2002). Philosophically, it inculcated a distinctly African epistemic cultural identity, an indigenous epistemological framework or unique African philosophy or order of knowledge, ideal for the maintenance of society (Durkheim, 1960; Higgs \& Van Niekerk, 2003; Mavhunga, 2009). European missionaries and colonisers decried it as primitive, heathen and savage (Nandwa \& Bukenya, 1992; Ranger, 1988) and this led to its relegation to an inferior position in many African societies (Murphree, 1975). Odora-Hoppers (2002) argues that what was needed was not a complete denigration of such knowledge form but a blend of it (indigenous knowledge system) with its Eurocentric counterpart for people not to feel marginalised because of a cultural heritage relegated to a peripheral role rather than being used as a springboard for the new kind of knowledge. It was for this reason that some of the dictates of Western forms of knowledge were not always well received by some of the African indigenous people who were the target beneficiaries (Challis, 1980; Mavhunga, 2009).

\title{
5. Fostering an Afrocentric Philosophy of Education for Indigenous Knowledge Systems
}

Discussing the role of introducing indigenous knowledge systems as a way of promoting and Afrocentric philosophy of education in the curriculum, Du Plessis and Du Plessis (2007) argue that following the introduction of the Language in Education Policy (LiEP) in 1997, post-apartheid South Africa established a more impressive array of language planning agencies and other language policy implementation institutions. In this sense an Afrocentric view of education took a perspective that Mahoso (2013) and Chivaura (2014) describe as homecoming or a form of homecoming. Philosophy of education as homecoming derives from the view that for four centuries, slavery, apartheid, and imperialism defined Africans as a people who should be educated and trained by strangers and be assisted to assume un-African and anti-African identities (Mahoso, 2013). Western media today still assume and teach this view. As a consequence of such a Eurocentric philosophy of education, the farther away from home those who acquired such an education went, the more prestige and honour they acquired (Chivaura, 2014).

From the aforementioned view, indigenisation and empowerment educational policies should thus start with education for homecoming and education as homecoming. The Afrocentric view of education for homecoming involves not only locating the true DNA and bloodline of the individual African educated by the European; it also implies Africans accepting and reclaiming who they are and what is theirs (Mahoso, 2013). It means being at home with their Africanness and their heritage as well as taking responsibility for its projection and its place in the universe. At the time of independence in 1980 for Zimbabwe and 1994 for South Africa, several songs were sung to celebrate the return of the freedom fighters from countries like Mozambique, Zambia, Tanzania among others where many Africans sought training and refuge from the imperialists who had annexed their homelands. One such song in Zimbabwe was:

\author{
Mauya, mauya, comrade \\ Zvamauyafundisai Zimbabwe \\ Mauya, mauya, comrade \\ Zvamauyafundayi Zimbabwe \\ Mauya, mauya, comrade \\ Zvamauyahamuchadzokera.
}


Another popular song in the Republic of South Africa, was:

\section{Obababethubaboshiwe, izinganeziselezodwa \\ Bazobuya, sibalindilenomabengenamali \\ Sithwelekanzimathina, sitwelekanzima}

Translated into English, the above verses, implies a welcome extended to former freedom fighters and detainees who returned home at independence after having been either in the battle fields fighting the imperialist or those who had been imprisoned like Nelson Mandela and others. The song called the returnees and detainees to now focus on rebuilding the African institutions that had been destroyed through cultural imperialism and to build their counties' education systems which had been alienated by the colonialists. It also called upon the returnees to adjust their life styles, learn more about their counties' needs and vow not to return to foreign lands. The Afrocentric philosophy of education sentiments echoed through the above songs clearly epitomise the notion of education as homecoming and education for homecoming. It also means, let education come to us not for us in Zimbabwe, South Africa, Zambia etc. It also implies that education needed to come to us Africans in our various tribal trust lands, ethnic groups, in Chipinge as in Harare, in Binga as in Beit Bridge, in Dande as in Dema, in IsiNdebele as in Shona, in Afrikaans, IsiZulu, Sesotho, Sepedi, Tshivenda and Setswana, Sesotho as in English. The philosophy also lampoons the Eurocentric mind-set whereby many Africans, owing to the influence of cultural imperialism had gotten into the habit or culture of migrating to Western countries, especially America and Europe pursuit for education on the misconception that education in Africa is inferior to that which is offered in Europe and America (Needham, 1984; Ranger, 1988).

Examining the impact of reintroducing indigenous knowledge systems in the curriculum for South Africans in pursuit of an African philosophy of education, Jansen (2003) and Mavhunga (2009) assert that educating the children in their mother tongue especially at the infancy school level has the potential to inculcate Afrocentric values and foster a better understanding of the taught content in the learners. This has culminated in many endeavours to teach learners in their vernacular languages where ever that was reasonably possible. In Zimbabwe, this philosophy saw the introduction of the Language Education Policy of 1987, which elevated the two main local languages to a position near English, which remained the medium of classroom instruction. The two dominant local languages, Shona and IsiNdebele were given much more power for use in the foundation phase of school education and considered important official languages where ever a population could not converse in English (Fortune, 1980; Mavhunga, 2009).

In South Africa the Language in Education Policy (LiEP) of 1997 or post-apartheid South Africa established a more impressive array of language planning agencies and other language policy implementation institutions (Jansen, 2003). Among the more important of these is the Pan South African Language Board (PANSALB), an independent statutory body, which has the mandate to advise central and provincial government on all matters pertaining to language policy and language use in education (Jansen, 2003). At approximately the same level, there is the National Language Service (NLS), which is the state's language arm located in the Department of Arts, Culture, Science and Technology and although many of the functions of these two super language planning agencies tend to overlap, the NLS is much more focused on practical issues of translation, interpreting and language technology (Geertz, 1993; Senge, 2008).

PANSALB has a provincial language body in each of the lexicographic unit, usually located in one or more universities (Senge, 2008). There are also 11 National Language Bodies, which have the task of seeing to the corpus development of the respective languages. Therefore, not to make use of the new LiEP in schools would be tantamount to retarding the realisation of the developmental potential of the concept of multi-cultural education as a condition necessary for democracy (Alexander, 2001). The above views show that the LiEP has been promoting indigenous knowledge systems and inter-group communication and understanding in school and society. This has resulted in the promotion of a multi-lingual education and the promotion framework for the country's indigenous knowledge systems as opposed to the over-reliance on the concept of a lingua franca only (Alexander, 2001; Jansen, 2003; Senge, 2008). This has also become the rationale for the official language education policy of additive bilingualism or the addition of other indigenous languages and the maintenance of the mother language concept in the South African school's Foundation phase teaching and learning systems.

\section{Benefits of Indigenous Knowledge Systems to Society}

Tapping into the intellectual resources associated with AIKS is not only cost effective but also relevant and in- 
dispensable, for environmentally and ecologically sensitive activity (Semali \& Kincheloe, 1999). It is at the level of economic sustainability, self-reliance and cost-effectiveness, however, that AIK continues to prove its viability and strength (Hountondji, 2005). The discourse of AIKS like conceptual Eurocentric knowledge forms also has specialists and technical operatives including, miners, metallurgists, textile manufacturers and food processors (Hosthemke, 2004). The interesting issue here is that many of the agents and agencies associated with the second economy, tap into the accumulated skills and expertise and indigenous knowledge systems, from traditional Africa. Emeagwali (2003) further notes that it is unfortunate that Africa in the $20^{\text {th }}$ century was afflicted by two major externally derived economic models of exploitation; the colonial model of exploitation and neocolonial models aimed at recolonization. The economic and epistemological access oriented aspects of those models were aimed at exploitation and mal-development. Built into those models were negative and unwholesome presuppositions about race, gender and segregationist policies as well as discriminatory modes of allocation of space, resources and infrastructure which prevailed (Geertz, 1993; Mavhunga, 2009). Export- oriented growth, monoculture, and outward-bound programs for the export of first stage mineral, agricultural extraction and even human resources were the dominant trends in most parts of the continent (Hountondji, 2005; Flavier, De Jesus \& Mavarro, 2009).

In south Africa, as in many parts of Africa, traditional education or socialisation passed on two types of indigenous knowledge to the younger generations: that which was necessary to carry out daily activities and occasional rituals in the household and village, and the body of traditional lore concerning natural phenomena, custom and tribal history (Cheater, Dorsey, Murphree, Dorsey, \& Mothobi, 1975). Such curricular content was taught at initiation ceremonies, in an informal way and often within the family. It was passed on through stories and riddles told by senior relatives and particularly by grandparents around the fire after the evening meal (Horsthemke, 2004). This constituted the principal indigenous knowledge education that was of the African child and was designed to prepare him or her for adult life in society (Hountondji, 2002). Odora-Hoppers (2002) adds that it tended to have an integrative function for a relatively non-competitive society whose main aim was the transmission of a common culture from one generation to the next and the maintenance of social cohesion. The curriculum had to ensure the recognition and acknowledgement of self-determining development, protection against colonisation, exploitation, appropriation and or commercialisation as well as legitimation and validation of indigenous practices and world views (Hountondji, 1995). It also incorporated condemnation of, or at least caution against, the subjugation of nature and general oppressiveness, non-indigenous rationality, science and technology (Horsthemke, 2004; Odora-Hoppers, 2002). In true Durkheimian tradition it was eminently suited to its milieu, before the coming of European settlers (Semali \& Kincheloe, 1999). The curriculum for boys in pre-colonial indigenous education covered, inter alia, gender-based roles such as inculcating hunting skills, herding cattle, fighting to defend one's national interests, preparation for adulthood, looking after wives and family (for boys ready to graduate into manhood), and observing social customs and traditions such as the prevention of incestuous relationships and marriages (Mukanya, 1994; Odora-Hoppers, 2002).

The elders of society, grandparents, uncles and aunts were tasked with the responsibilities of enculturation because Africans have always believed that age and experience represent wisdom (Horsthemke, 2004). As a result, the use of oral literature as a means of enhancing cultural transmission involved society's senior citizens, believed or known to be talented in oratory or teaching of conversational skills (Odora-Hoppers, 2002). They taught this at initiation ceremonies and families and within other traditional society's general structures and gender-based gatherings typical of many African societies. For girls, the indigenous knowledge curriculum comprised teaching them how to look after themselves, how to become good wives, avoiding immoral behaviour or moral decadence, looking after children, respecting their husbands and in-laws as well as enduring the hardships of marital life, being generous with food and working hard in the home or private sphere (Barnes et al. 1994; Judges Commission, 1962; Mukanya, 1994). For girls, society tasked grandparents and aunts with the responsibility of ensuring that the above stated attributes were nurtured (Mukanya, 1994; Ranger, 1988). The methods of transmitting this knowledge took many forms of oral literature, such as folktales, riddles, proverbs, idioms, fables, myths, legends and fairy tales (Jenkins, 2006; Nandwa \& Bukenya, 1992).

It was not until the turn of the nineteenth century, after the establishment of European settlement in 1890 and the extension of political control, that missions were able to expand and African interest in Western education increased, albeit slowly at first. Pursuing a Eurocentric school curriculum was the only medium through which the younger generation would be able to understand and cope with the new society that had been introduced to the country. It seemed to be the only reasonable avenue to European type occupations and ways of living, and 
became increasingly valued among the African people, especially as traditional conceptions of social status were replaced by criteria of occupation, education and the adoption of European patterns of life (Murphree et al., 1975; Ranger, 1988). Thus, while the settler government's concern (and even the views of most missionaries) was that African educational activities should follow a practical educational curriculum, which would not estrange them from their community life, African expectations and aspirations, it soon ran counter to this. Having adopted a European culture as their reference point, they wished to have a type of education curriculum similar to that provided for Europeans, essentially an academic one (Cheater, Dorsey, Mothobi, \& Murphree, 1975).

The Africans expected the curriculum to enable them to obtain employment in the European community and to enjoy a standard of living different from that of their fathers. An educational curriculum that did not purport to do so was viewed with dismay and a suspicion that it was preparing the African children for an inferior social status. Even when this government started its first school for Africans in 1920 and 1922, specifically to give them industrial and agricultural training, it soon realised that it had to give in to African pupils' demands for increases in academic instruction (Atkinson, 1972). The school curriculum became inextricably linked to the patterns of European colonisation in the region and the dominant role of the British settler regime (Jansen 2003; Mungazi, 1995). As in Britain, girls were educated for domesticity, whilst boys were amply prepared for employment and the role of family head and breadwinner (Gordon, 1995: p. 13; Flavier, De Jesus, \& Mavarro, 2009).

According to Atkinson et al. (2003), the colonial settler government officials tended to visualise girls and women in terms of a Victorian image of what a woman should be, whereas they equated men with breadwinners. As a result, they introduced technologies to men and recruited them for better paying and more highly esteemed jobs, which often took them off the homes, farms and their rural areas, then called 'tribal trust lands' (Atkinson et al., 2003). Boys were also channelled into technical subjects, such as metalwork, woodwork, agriculture, technical graphics, and building, and encouraged to pursue science subjects. Girls were offered domestic science, typing and shorthand, and encouraged to pursue arts subjects (Mavhunga, 2009). This trend continued with the expansion of an international market economy, with men migrating to work in the mines, plantations and towns (Mawarire, 2007). Men were favoured for education, employment and access to resources, and even land settlement schemes gave title deeds to men (Kwinjeh, 2007). This meant they had automatic rights to the proceeds of the land, including the products of women's labour. The colonial period can therefore be viewed as having set the scene for unequal educational and career aspirations between males and females and their subsequent unequal access to economic sustainability (Machingura, 2006).

Following missionary excursions in South Africa and other parts of Africa and subsequent colonisation, schooling expanded phenomenally (Atkinson et al., 2003). The first government high school for Africans was opened in 1946 at Goromonzi and, by 1950, five missions had become involved in secondary education and enrolment in primary schools more than doubled (Gray, 1988). During the same period, employment opportunities increased and more Africans migrated to the urban areas. Missions found it beyond their resources to cope with the increased demand and so government assumed responsibility for African education in the urban areas while missions remained responsible for it in the rural areas (Chavunduka, 2005). In 1947, government also accepted responsibility for the payment of grants for salaries of all approved teachers and equipment and supervision grants were increased. As the Kerr Commission (1952: p. 3) pointed out, it was not until then that government contribution began to equal and then surpass the annual contribution of the combined missions, though this evaluation did not include the accumulated capital expenditure by missions on school buildings.

The Commission made recommendations that included the need to increase participation by girls in education, since they were under-represented in the village schools because of traditional views about the position and role of females in society. Even though the recommendations did not yield immediate change in the schools (Cheater, et al., 1975), the Judges Commission of 1974 still recommended parity for boys and girls at levels where it was considered feasible, particularly at the sixth-form and training college levels. It also strongly recommended the development of a common policy for the education of all children in the country. As a result, public taxation became based on the size of local populations and not race. The commission thus marked the beginning of debates on racial disparities and gender biases within Zimbabwe.

Townsend, Madhavan, Tollman, Garenne and Kahn (2002), working in rural South Africa, used the constellation of social relationships of which pupils were part to explain how their access to physical, social, economic or cultural resources was as diverse as access to information, food and shelter, employment prospects or career aspirations and choices. Some of the most important of these relationships had to do with residential household or 
domestic units (Townsend et al., 2002). Sociologically, this is an argument that looks at the relationship between success or failure in education and individual effort (agency), which is whether it is predetermined by the individual's family background or the calibre of the school attended (structure).

South Africa's Curriculum development unit has produced successive curricula (Jansen, 2008) and have looked at possibilities and problems of changing the underlying ideological commitments of the inherited curriculum to forge a new educational dispensation or social order. Every major curricular innovation had been the subject of intense study, but close scrutiny of the themes shows that all curricular reforms in the post 1994 educational era have sought to entrench an anti-colonial political stance in education (Jansen, 2003) with very little attention given to the need to promote indigenous knowledge systems through educational institutions. Advocates of IKS, for example, O’Donogue, Masuku, Janse van Rensburg, \& Ward (2001) argue that the pre-colonial education system in Africa was embedded within the rich culture of the people. For them, it recognized the importance of traditional knowledge systems involving processes that were useful to indigenous people and enabled them to sustain their livelihood (Chavunduka, 2005; Vilakazi, 1999). The environmental crises they experienced were responded to with failure at times, and success at times, as the trial and error methods were seen to be effective (O’Donoghue et al., 2001). Perhaps the endeavours directed at sustainable economic development in Africa depend on the utilization of all the knowledge systems in order that they may complement the strengths and weaknesses of each other. Therefore, the urgency with which our education curricula should be transformed to meet the needs of Africa (Ntuli, 2009) and South Africa in particular is of vital importance. Ntuli further asserts that the role of higher education and that of the intelligentsia lie in shaping the direction toward a more culture specific or culturally relevant curriculum for institutions of learning. Similar sentiments are expressed by Vilakazi (1999) who maintains that Africa needs to formulate and implement policies which would result in initiating an Afrocentric educational revolution, to be able to serve her millions of people adequately and lay a basis for industrialisation and modernization. The aforementioned clearly shows that AIKS or traditional knowledge processes remain invaluable in an education system that envisages the integrate all processes of knowing in order

\section{Conclusion}

The conclusion reached in this discussion is that the integration of AIKS in all of the education curricula for Africans needs to be carefully and appropriately carried out in virtually all learning situations. The Eurocentric mind-set that tends to regard IKS as an integral part of the Arts and Culture Learning curriculum needs to be revisited with a view to making IKS a compulsory part of all teaching and learning situations consistent with the sociological view that all knowledge, whether indigenous or western, is spawned within a particular segment of society based on power and class. A view that Aronowitz and Giroux (2005) use to argue that learning institutions play a particularly important role in legitimizing and producing dominant cultural capital through the hierarchically arranged bodies of school knowledge is presented. The discussion also concluded that hegemonic western forms of knowledge, which continue to be given high status in the school curriculum, are not necessarily the panacea to the social, economic and political problems Africa faces. The study also concluded that an over-emphasis on the superiority of western hegemonic forms of knowledge tends to relegate AIKS to an inferior position leading many Africans to shy away from its pursuit.

\section{Recommendations}

The recommendations made from this study are that for AIKS to be regarded as invaluable, the intelligentsia (Gramsci, 1971) as its custodians need to revisit their educational curricula with a view to aligning them to the needs of Africa based on the available resources at hand. A progressive and robust approach to the transformation of education to address this crucial issue of the disparity in the utilization of traditional knowledge systems, is critical to the process of emancipating traditional knowledge in both the African and international perspective. The uncertificated and illiterate rural women and men need to be viewed only as illiterate in so far as the western educational paradigms are the standards of evaluating their knowledge. Because an African perspective tends to be used to measure what the so-called illiterate, rural person knows in his or her cultural and historical setting, the result is that a so-called intellectual might find himself or herself wanting in this regard. Accordingly, a number of intellectuals and academics consult traditional healers whom it is assumed are illiterate according to western standards. If these academics and intellectuals had possessed the traditional knowledge of healing, it 
would be unnecessary to consult traditional healers It is also in this sense that the paper recommends that strong Afrocentric view of AIKS be regarded as necessary for the establishment of a pathway towards the consolidation of democratic forms of knowledge production and if this is to be carried out within the context of openness and empathetic critical research, curricular planners and designers in Africa would need to ensure that they adopt a paradigm shift towards AIKS as valuable systems of knowledge to be clearly stated in education policies.

\section{References}

Adam, J. S., \& Stamps, D. (Eds.) (2003). King James Version: Life in the Spirit Study Bible. Grand Rapids, MI: Zondervan. Alexander, J. (2001). Analytic Auto-Ethnography. Journal of Contemporary Ethnography, 35, 373-395.

Atkinson, N. (2003). Teaching Rhodesians: A History of Educational Policy in Rhodesia. London: Longman

Aronowitz, S., \& Giroux, H.A. (2005). Education under Siege: The Conservative, Liberal and Radical Debate over Schooling. London: Routledge \& Kegan

Barnes, T., Mutwira, R., \& Drew, M. (1994). People Making History, Book 4. Harare: Zimbabwe Publishing House.

Blackledge, D., \& Hunt, B. (2005). Sociological Interpretations of Education. London: Routledge.

Bourdieu, P. (2002). The School as a Conservative Force: Scholastic and Cultural Inequalities. London: Routledge \& Kegan Paul.

Brokensha, D., Warren, D. M., \& Werner, O. (Eds.) (2000). Indigenous Knowledge Systems and Development. Washington, DC: University Press of America.

Challis, R. (1980). The European Educational System in Southern Rhodesia, 1890-1930. Zambezia, 1, 1-11.

Chavunduka, M. (2005). The Missing Links. Keynote Address to the Workshop on the Study and Promotion of Indigenous Knowledge Systems and Sustainable Natural Resources Management in Southern Africa. Midmar, KwaZulu-Nata l, 24 April.

Cheater, G., Dorsey, B., Mothobi, D., \& Murphree, M. (1975). Education, Race and Employment in Rhodesia. Salisbury: Association of Round Tables in Central Africa, Centre for Inter-Racial Studies.

Chivaura, V. G. (2014). Progress on Meeting SADC Education Targets. Zimbabwean, 4, 19-25.

Christie, P. (2008). Changing Schools in South Africa: Opening the Doors of Learning. Johannesburg: Heinemann.

Christie, P., \& Collins, C. (1990). Bantu Education: Apartheid Ideology or Labour Reproduction? Comparative Education, 18, 59-75. http://dx.doi.org/10.1080/0305006820180107

Christie, P. (1992). Reforming the Racial Curriculum: Curriculum Change in Desegregated Schools in South Africa. British Journal of Sociology of Education, 11, 37-48. http://dx.doi.org/10.1080/0142569900110103

Crossman, A. (2012). Sociological Theories. London: Methuen.

Du Plessis, P. (2007). Understanding Cultural Diversity in Schools. Journal of Social sciences, 15, 47-59.

Durkheim, E. (1960). School and Society. New York: Polity Press.

Flavier, J. M., De Jesus, A., \& Mavarro, S. (2009). Regional Program for the Promotion of Indigenous Knowledge in Asia. In D. M. Warren, L. J. Slikkerveer, \& D. Brokensha (Eds.), The Cultural Dimension of Development: Indigenous Knowledge Systems (pp. 69-73). London: SRP, Exeter.

Fortune, G. (1980). The Bantu Languages of the Federation: A Preliminary Survey. Cape Town: Juta.

Frank, A. G. (1972). Re-Orient: Global Economy in the Asian Age. New Deli: Amazon

Geertz, C. (1993). The Interpretation of Cultures. New York: Basic Books.

Gettier, J. (1963). Review of the Value of Indigenous Knowledge Education Systems. Journal of Social Development in Africa, 23, 121-123.

Gordon, R. (1995). Educational Policy and Gender in Zimbabwe. Zimbabwe Journal of Educational Research, 13, 10-18.

Green, E. (2006). Indigenous Knowledge Systems and Health Promotion in Mozambique. In H. Norman, I. Snyman, \& M. Cohen (Eds.), Indigenous Knowledge and Its Use (pp. 107-109). London: SRP, Exeter.

Higgs, P., \& Van Niekerk, M. P. (2003). The Programme for Indigenous Knowledge Systems (IKS) and Higher Educational Discourse in South Africa: A Critical Reflection. South African Journal of Higher Education, 16, 38-49. http://dx.doi.org/10.4314/sajhe.v16i3.25215

Horsthemke, K. (2004). Indigenous Knowledge: Conceptions and Misconceptions. Journal of Education, 32, 31-35.

Hountondji, P. (2002). Knowledge Appropriation in a Post-Colonial Context. In C. Odora-Hoppers (Ed.), Indigenous 
Knowledge and the Integration of Knowledge Systems: Towards a Philosophy of Articulation (pp. 137-142). Claremont, South Africa: New Africa Books.

Hountondji, P. (2005). African Philosophy: Myth and Reality. Bloomington, IN: Indiana University Press.

Jansen, J. (2003). What Education Scholars Write about Curriculum in Namibia \& Zimbabwe. In W. Pinar (Ed.), International Handbook of Curriculum Research (pp. 78-84). Hillsdale, NJ: Lawrence Erlbaum.

Jenkins, R. (2006). Social Identity. London: Routledge.

Jansen, J. (2008). Knowledge in the Blood. Cape Town: UCT Press.

Judges Commission (1974). Government Report for the Southern Rhodesia Commission of Inquiry into Education and Training for Africans (pp. 41-45). Salisbury: Government Printers.

Kerr Commission (1952). Southern Rhodesia Government Report of the Native Education Inquiry. Salisbury: Government Printers.

Language in Education Policy Document (LiEP) (1997). South Africa’s Language in Education Policy. Pretoria: Government Printers.

Le Grange, L. (2000). Is There "Space” for Enabling Disparate Know Ledge Traditions to Work Together? Challenges for Science (Education) in an African Context. South African Journal of Education, 20, 114-117.

Machingura, V. (2006). Women’s Access to Teacher Education: A Gender Profile. Zimbabwe Bulletin of Teacher Education, $13,21-34$.

Mahoso, T. (2013). The Death of the Dollar. Zimbabwean, 3, 13-17.

Mahoso, T. (2014). Towards an African Philosophy of Education. Zimbabwean, 5, 4-6.

Maila, M., \& Loubser, C. (2003). Emancipatory Indigenous Knowledge Systems: Implications for Environmental Education in South Africa. South African Journal of Education, 23, 276-280.

Maila, M. (2001). The Assessment of Learning Programmes for the Senior Phase at Environmental Education Centres in Mpumalanga. Unpublished Master's Dissertation, Pretoria: University of South Africa.

Marconnes, F. (1988). The Rozvi Kingdom. NADA Journal, 11, 87-88.

Masuku-Van Damme, L. (2007). Indigenous Knowledge within Environmental Education Processes. EnviroInfo, 26-28.

Mavhunga, P. (2009). Africanizing the Curriculum: A Case of Zimbabwe. Zimbabwe Journal of Educational Research, 2, 31-37.

Mawarire, J. (2007). Locating Women and the Feminist Discourse in Zimbabwean Transitional Politics. Journal of Alternatives for a Democratic Zimbabwe, 1, 1-11.

McNeely, J. A. (2009). IUCN and Indigenous People: How to Promote Sustainable Development. In D. M. Warren, L. J. Slikkerveer, \& D. Brokensha (Eds.), The Cultural Dimension of Development: Indigenous Knowledge Systems (pp. 37-44). London: SRP, Exeter.

Mukanya, S. (1994). Dynamics of History. Harare: College Press.

Mungazi, D. (1995). Educational Policy for Africans and Church-State Conflict during the Rhodesian Front Government in Zimbabwe. Proceedings of the National Social Science Conference, Philadelphia, 53-55.

Murphree, B. (1975). Employment Opportunity and Race in Rhodesia. Denver: University of Denver Press.

Murphree, B., Cheater, G., Dorsey, B., \& Mothobi, D. (1975). Education, Race and Employment in Rhodesia. Salisbury: Centre for Inter-racial Studies, University of Rhodesia.

Nandwa, B., \& Bukenya, C. (1992). Oral Literature in Africa. Mombasa: McMillan.

Needham, D. (1984). From Iron Age to Independence: A History of Central Africa. London: Longman.

Ntalaga, N. (2005). Interrogating the Notion of Development from a Modernization Paradigm. Journal of Social Sciences, 12 , 311-323.

Ntuli, P. (2009). The Missing Link between Culture and Education: Are We Still Chasing Gods That Are Not Our Own? In M. W. Makgoba (Ed.), African Renaissance (pp. 67-72). Cape Town: Mafube-Tafelberg.

Odora-Hoppers, C. (2002). Indigenous Knowledge and the Integration of Knowledge Systems: Towards a Conceptual and Methodological Framework. In C. Odora Hoppers (Ed.), Indigenous Knowledge and the Integration of Knowledge Systems: Towards a Philosophy of Articulation (pp.139-143). Claremont, South Africa: New Africa Books.

O’Donoghue, R., Masuku, L. J., van Rensburg, E., \& Ward, M. (2001). Indigenous Knowledge in/as Environmental Education Processes. EEASA Monograph, No. 3, Howick: Share-Net.

Ranger, T. (1988). Peasant Consciousness and Guerrilla War in Zimbabwe. Harare: Zimbabwe Publishing House.

Semali, L., \& Kincheloe, J. (1999). What Is Indigenous Knowledge? Voices from the Academy. New York: Falmer Press. 
Senge, R. (2008). Community Action Research: Learning as a Community of Practitioners, Consultants and Researchers. In P. Reason, \& H. Bradbury (Eds.), Handbook of Action Research (pp. 196-210). London: Sage.

Townsend, N., Madhavan, S., Tollman, S., Garenne, N., \& Kuhn, K. (2002). Children's Residence Patterns and Educational Attainment in Rural South Africa. Population Studies, 56, 215-225. http://dx.doi.org/10.1080/00324720215925

Vilakazi, H. (1999). The Problem of African Universities. In M. W. Makgoba (Ed.), African Renaissance (pp. 127-132). Cape Town: Mafube-Tafelberg.

Webster, A. (2008). The Sociology of Development. New York: Routledge. 